\title{
Paradigm of Propaganda
}

\author{
Alexandra lorgulescu \\ University of Craiova, 13 A. I. Cuza Street, 200585, Craiova, Romania \\ E-mail address: daniamanolea@yahoo.com
}

\begin{abstract}
In this analysis of the paradigm of propaganda, we have dealt with only a few of the most relevant characteristics of what we consider to be a "historical experience", a fact the evolution of which has been the subject of many researches we took into account. There are of course, many other important consequences of the phenomenon itself which it will be dealt with in detail during our informative research.
\end{abstract}

Keywords: communication; information; manipulation; propaganda

\section{INTRODUCTION}

We witness daily the phenomenon of subordination of media of social-political objectives and mass-media coordination in the official propaganda system. Defined by some experts as "an essential form of communication, perhaps the most important form of social communication beyond the interpersonal communication", New Propaganda includes both the publicity and the public relations, therefore it is complete (Combs \& Nimmo, 1992) and deals with the ephemeral interests of the masses. This term does not represent a rupture from the previous propaganda, but a direct continuation with manifestations of the type of election campaigns and Public Relations. Its system of techniques uses the mass-medial also as a mechanism to constrain the masses in addition to the function of transmission relay. Regarding the external characteristics, it simultaneously deals with the individual and the masses, it uses all available technical means (press, radio, television, brochures, cinema), it is continuous and long in order to cause the adhesion and urge the receiver to action" (Bertrand, 2001; Borowski, 2014).

\section{TAXONOMIES OF PROPAGANDA}

According to researchers, the internal operation of propaganda is done according to five "laws" aimed to create the conditioned reflexes and not human rationality, particularly relying on the emotional effect.

They are:

- Rule of simplification (not very complicated subjects that would stimulate the energies on a single individual in charge); 
- The rule of thickening and disfiguration (conscious amplification of facts);

- Rule of orchestration (designing the messages according to the target-audience and their constant repetition in order to divert the attention from something else);

- Rule of transfusion (indicating own prejudices in order to destabilise the convictions of others);

- Rule of unanimity and contagion, identical with the individuals' appetite for conformism (Auby \& Ducos-Ader, 1982).

The first theorist of propaganda, Niccolo Machiavelli, is considered a predictor of contemporary political marketing. "To govern - he says - means to make people believe", in the context where the "people always judge by appearances". Forerunner of some contemporary realities such as image (of a politician), positioning (of the product) where rhetoric and television are in a total symbiosis, Machiavelli was considered by Jacques Ellul "the theorist of appearance" (1962).

Propaganda has undergone a multitude of definitions due to the different way to deal with the concept and locate it in the general context of mass communication (Dima \& Vlăduţescu, 2012; Vlăduţescu, 2013; Vlăduţescu, 2014).

From a social-political perspective, the term of propaganda expresses a "specific form of mass persuasion (involving the production and transmission of some specifically structured texts and messages) designated to generate or encourage certain reactions of the mass audience" (Concepte fundamentale din ştiinţele comunicării şi studiile culturale, 2001). Since the communist period, when it had acquired positive connotations and until now when it becomes a negative identity, the term deteriorated due to the frequency at which it is used in political, social communication and in the press (Grabara, Modrak \& Dima, 2014; Bosun \& Modrak, 2014; Bosun \& Grabara, 2014).

This is why it is nowadays identifies with the deliberate distribution of information, rumours, ideas with the purpose to destabilise movements, beliefs, institutions or governments. We are facing that type of contemporary propaganda, specific to the $20^{\text {th }}$ Century, which has become total and permanent, because "it uses the entire media, including the content of cultural industries, school, so that no segment of the audience remains untouched" (Popescu, 2002).

For the practitioner of (communist) propaganda, V. I. Lenin, it is continuous, just as the class fight and its major purpose is to indoctrinate the masses by means of agitators, by censorship and by truncated, diverted, altered information subservient to own interests (Bajdor \& Grabara, 2014; Siminică \& Traistaru, 2013; Traistaru \& Avram, 2014).

Serge Tchakhotine (1939) designs an organised structure of the relation of propaganda messages in the form of a pyramid: doctrine provides the base that results in a program, in a synthesised manner, in its turn into a slogan focused on a symbol that "the more suggestive it is, the more efficient it is; in other words, it transmits the idea of action related to the movement it represents and especially the emotional basis which this movement reaches: threat, compassion, material interest, etc".

The true propagandists realise the reality that propaganda can no longer be done starting from nothing and it can no longer be imposed to masses any idea, regardless of the moment. "Any public speaker knows the principle that one should never openly contradict a crowd, but one should start by declaring they agree with it, by placing oneself in agreement with it before kneeling it" (Domenach, 1952).

The reality of affirming the propaganda rather in democratic regimes than in totalitarian systems is obvious, becoming dominant in the $20^{\text {th }}$ Century by addressing some manipulating symbols and speeches. In most cases, the simple concepts tend to master people's spirit. Therefore, a veridical, yet complex idea will not have the force of a false one expressed 
however with transparency and accuracy. In this case, we cannot neglect the involvement of the press by constantly presenting to the public some absolutely incomprehensible phenomena and states, such as corruption, political tensions, revenge, arrests, punishments, etc. Over time, disinformation and propaganda have been true "weapons" used by those in power to manipulate the masses in favour of the government. "Constituting as a system of persuasion techniques aiming to change the behaviour of the public in relation with ideas, social practices, personalities, propaganda is based on a manipulative argument, since the message transmitted is deliberately distorted, in order to reach a precise objective (Roşca, 2002; Grabara, Kolcun \& Kot, 2014; Grabara, Man \& Kolcun, 2014).

We tend to believe that there are similarities between advertising and propaganda through repeated attempts to transform or confirm opinions, but its purpose is a political one and not a commercial one.

Jean Cazeneuve (1976) identifies three types of contemporary propaganda:

- Competition propaganda (easy to identify in election campaigns, it has as objective the political change accepted by the society, representing an "organised conflict"). It also approaches advertising, because it aims at establishing, consolidating or rather cancelling the prestige of the personality in question. The focus is on communication, characterised by specialists through conceptual ambiguity, through the ubiquity of phenomena in relation with the political field, the discursive practices becoming political practices. The current political life is characterised by a continuous effort to communicate the political figures, in order to legitimise the actions, the stake being the election. Therefore, referentiality is always present in the performative use of language through the dimension of meaning, without any solid connection with the reality, the speaker turning to a number of "language" or "meaning games", which prove to be purely "linguistic speculations".

- Propaganda of integration. In this case, a privileged position is held by education (the education system), and also by Public Relations (particularly the area of Public Affairs). According to the specialist Jackues Ellul (1962), the essence of this type of propaganda would subordinate other two branches: The vertical one (designed by a leader who authoritatively acts manipulating the crowd located on a position of inferiority) and the horizontal one, which uses the "dynamics of groups". He concludes that vertical propaganda is ideological and the horizontal one is sociological (the Chinese model and the American model, as Human Relations.)

- Propaganda of subversion specific to a political organisation, which aims to acquire power through force.

\section{CONCLUSION}

The picture of the political life in our country, viewed in close-up, is a political stage in continuous activation, where politicians are in a constant oscillation between their own interest and the national one, determining the journalists to think true prophecies (most of the time negative ones), because the impact is greater. In this case, the idea that the press is tributary to some classical stereotypes in the collective mentality: it is the obvious case of the eternal complex of inferiority which we, Romanians, are marked of, permanently supervised, delayed, controlled and directed by Europe. 


\section{References}

[1] J. M. Auby, A. R. Ducos (1982). Droit de la comunication. Paris: Dalloz.

[2] A. Borowski, International Letters of Social and Humanistic Sciences 14 (2014) 7-17.

[3] P. Bosun, V. Modrak, International Letters of Social and Humanistic Sciences 14 (2014) 66-72.

[4] J.-C. Bertrand (2001). O introducere în presa scrisă şi vorbită. Iaşi: Editura Polirom.

[5] J. Cazeneuve (1976). La Commnunication de Masse Guide alphabetique. Paris: Denoël/Gonthier.

[6] Ştefan Vlăduţescu, European Scientific Journal 9(32) (2013).

[7] J. E. Combs, D. Nimmo (1992). New Propaganda. The Dictatorship of Palaver. New York / London: Longman.

[8] Andrzej Borowski, International Letters of Social and Humanistic Sciences 4 (2013) $70-74$.

[9] J. Ellul (1962). Propagandes. Paris: Armand Colin.

[10] Janusz Grabara, Vladimir Modrak, Ioan Constantin Dima, International Letters of Social and Humanistic Sciences 15 (2014) 138-147.

[11] Ş. Vlăduţescu, International Letters of Social and Humanistic Sciences 10 (2014) 100-106.

[12] Mioara Nedelcu (2005). Marketingul politic. Iaşi: Editura Universităţii „A.I. Cuza”.

[13] Andrzej Borowski, International Letters of Social and Humanistic Sciences 2 (2014) 110-121.

[14] Ş. Vlăduţescu, International Letters of Social and Humanistic Sciences 13 (2014) 71-78.

[15] Luminiţa Roşca, Revista Română de Ştiinţe ale comunicării 1(1) (2002).

[16] M. Colhon (2013). Automatic Lexical Alignment between Syntactically Weak Related Languages. Application for English and Romanian. In Computational Collective Intelligence. Technologies and Applications (pp. 266-275). Springer Berlin Heidelberg.

[17] Luminiţa Roşca, (2000). Formarea identităţii profesionale a jurnaliştilor. Iaşi: Polirom.

[18] Ş. Vlăduţescu, E. M. Ciupercă (2013). Next Flood Level of Communication: Social Networks. Aachen: Shaker Verlag.

[19] Cristian Florin Popescu, Revista Română de Ştiinţe ale comunicării 1(1) (2002).

[20] Andrzej Borowski, International Letters of Social and Humanistic Sciences 6 (2013) $86-90$.

[21] T. O’Sullivan, J. Hartley, D. Saunders, M. Montgomery (2001). Concepte fundamentale din ştiinţele comunicării şi studiile culturale. Iaşi: Polirom.

[22] Ştefan Vlăduţescu (2014). Convictive Communication and Persuasive Communication. International.

[23] Janusz Grabara, Michal Kolcun, Sebastian Kot, International Journal of Education and Research 2(2) (2014). 
[24] F. Hristea, M. Colhon, Fundamenta Informaticae Journal 119(1) (2012) 61-86.

[25] P. Bosun, J. Grabara, International Letters of Social and Humanistic Science 14 (2014) 59-65.

[26] A. Traistaru, M. Avram, International Letters of Social and Humanistic Sciences 13 (2014) 79-88.

[27] I. C. Dima, Ş. Vlăduţescu (2012). Persuasion elements used in logistical negotiation: Persuasive logistical negotiation. Saarbrucken: LAP Lambert Academic Publishing.

[28] M. Siminică, A. Traistaru (2013). Self-Directed Learning in Economic Education. International.

[29] Sebastian Kot, Jwona Grabara, Michal Kolcun, International Letters of Social and Humanistic Sciences 15 (2014) 1-6.

[30] M. Coman (1999). Introducere în sistemul mass-media. Iaşi: Polirom.

[31] Ştefan Vlăduţescu (2013). What Kind of Communication Is Philosophy. Jokull.

[32] J.-M. Domenach (1952). La Propagande Politique. Paris: PUF.

[33] B. M. Dascălu (2014). Echivocul imagologic în Caietele lui Emil Cioran. Studii de Ştiinţă şi Cultură.

[34] P. Bosun, V. Modrak, International Letters of Social and Humanistic Sciences 14 (2014) 66-72.

[35] Paula Bajdor, Iwona Grabara, Journal of Studies in Social Sciences 7(2) (2014).

[36] Ștefan Vlăduțescu (2013). Principle of the Irrepressible Emergence of the Message. Joku 11.

[37] Janusz Grabara, Mariana Man, Michal Kolcun, International Letters of Social and Humanistic Sciences 15 (2014) 148-156.

[38] Andrzej Borowski, International Letters of Social and Humanistic Sciences 11 (2014) $1-168$.

[39] Jason L. Powell, International Letters of Social and Humanistic Sciences 16(1) (2014) 19-30.

[40] Kabiru Ibrahim Yankuzo, International Letters of Social and Humanistic Sciences 4 (2014) 1-8. 